\title{
Profile and Reference Values for Body Fat and Skeletal Muscle Mass Percent at Females, Aged from 18.0 to 69.9, Measured by Multichannel Segmental Bioimpedance Method: Serbian Population Study
}

\author{
Perfil y Valores de Referencia del Porcentaje de Grasa Corporal y Masa Muscular en \\ Mujeres, con Edades Comprendidas entre 18,0 y 69,9 Años, Medido por el Método de \\ Bioimpedancia Segmentaria Multicanal: Estudio en Población Serbia
}

Rakic Sladjana $^{1}$; Dopsaj Milivoj ${ }^{1,5}$; Djordjevic-Nikic Marina ${ }^{1}$; Vasiljevic Nadja ${ }^{2}$; Dopsaj Violeta ${ }^{3}$; Maksimovic Milos²; Tomanic, S. Milena ${ }^{2} \&$ Miljus Dragan ${ }^{4}$

RAKIC, S.; DOPSAJ, M.; DJORDJEVIC-NIKIC, M.; VASILJEVIC, N.; DOPSAJ, V.; MAKSIMOVIC, M.; TOMANIC, S. M. \& MILJUS, D. Profile and reference values for body fat and skeletal muscle mass percent at females, aged from 18.0 to 69.9, measured by multichannel segmental bioimpedance method: Serbian population study. Int. J. Morphol., 37(4):1286-1293, 2019.

SUMMARY: Profile and standards for the diagnostics of percent of body fat and muscles were defined on a sample of 1924 women from the Republic of Serbia, aged 18.0 to 69.9, where the body structure of subjects was measured by applying multichannel segmental bioimpedance. Total sample was divided into six age groups, for the purpose of the definition of standard with regards to age. When it comes to body fat percentage results have shown that the average value of the total sample was $28.51 \pm 9.26 \%$, and between the range of 23.81 and $39.94 \%$ for age groups 18.0-19.9 $\mathrm{yr}$ and 60.0-69.9 yr, respectively. Regression analysis results have shown that the constant of body fat percentage increase by trend of $3.417 \%$ per decade, and that $25.1 \%$ of mutual variance trend was explained by the model, with prediction error of $4.55 \%$. With regards to the percentage of skeletal muscles in the body, the results have shown that the average value of the total sample was $39.30 \pm 5.25 \%$, and within the range of 42.25 to $32.58 \%$ for age groups 18.0-19.9 yr and 60.0-69.9 $\mathrm{yr}$, respectively. Regression analysis results have shown that the constant of the skeletal muscles decrease by tend of $-2.016 \%$ per decade and that the model explained $23.8 \%$ of mutual variance trend with prediction error of $8.08 \%$.

KEY WORDS: Females; Body Composition Profile; Bioimpedance; Body Fat; Skeletal Muscle Mass.

\section{INTRODUCTION}

It is a global fact that the modern way of life is characterized by sedentariness or insufficient level of physical activity (Haskell et al., 2007; Owen et al., 2010; Maksimovic et al., 2016). Being very useful on the one hand, technical achievements of civilization negatively impact life quality on the other hand, which relates to the health aspect in particular, where non-infectious diseases are concerned. Unfortunately, the business aspect and business sector to which the modern man belongs, condition increasing physical passivity, because thanks to workplace modernization all the work is being done in a sitting position. On the other side, even though the modern age man has an ever increasing amount of free time, the population has become increasingly physically inactive, the main reasons being computer use, the Internet, mobile phones and watching television (Hallal et al., 2012). Additionally, via the phenomenon of the cause-effect connection, lack of physical activity has as a consequence led to decreased motivation for practicing it (Sallis et al., 2015). Unfortunately, overabundant and irregular diet, in addition to physical activity that is inconsistent and of insufficient scope, are increasingly becoming dominant habits and a comprising part of modern man's life (Menotti et al., 2014; Maksimovic et al.).

\footnotetext{
${ }^{1}$ Faculty of Sport and Physical Education, University of Belgrade, Belgrade, Serbia.

${ }^{2}$ Institute of Hygiene and Medical Ecology, Faculty of Medicine, University of Belgrade, Belgrade, Serbia.

${ }^{3}$ Pharmaceutical Faculty, University of Belgrade, Belgrade, Serbia.

${ }^{4}$ Institute of Public Health of Serbia "Dr Milan Jovanovic Batut", Belgrade, Serbia.

${ }^{5}$ SUSU, South Ural State University, Institute of Sport, Tourism and Service, Chelyabinsk, Russia.
} 
RAKIC, S.; DOPSAJ, M.; DJORDJEVIC-NIKIC, M.; VASILJEVIC, N.; DOPSAJ, V.; MAKSIMOVIC, M.; TOMANIC, S. M. \& MILJUS, D. Profile and reference values for body fat and skeletal muscle mass percent at females, aged from 18.0 to 69.9, measured by multichannel segmental bioimpedance method: Serbian population study. Int. J. Morphol., 37(4):1286-1293, 2019.

According to data from many scientific studies the phenomenon of hypokinesis, i.e. insufficient physical activity, has become the global public health problem in the 21st century (Hallal et al.), while epidemiological studies have shown that three factors, such as: bad diet, stress connected to the modern way of life and hypokinesis, are the main cause of increase in the prevalence of non-infectious diseases (Haskell et al.; Owen et al.; Menoti et al.).

A system for controlling the status of body composition, through continued monitoring of the given state of the organism, is increasingly becoming a part of the very important health mechanism with the goal of tracking the condition and ascertaining the trends of change in the given conditions among the general populace (Gába \& Pridalová, 2014; Ihász et al., 2015) or some specific population, such as athletes, regardless of sex, age or type of sport (Dopsaj et al., 2017; Bankovic et al., 2018). Also, defining the characteristics of the model for the body composition status condition among people represents an expert and scientific attitude of decision making on whether a certain tissue component is insufficiently, normally or predominantly represented in the body (Bankovic et al.; Saraykin et al., 2018), that is, if there exists an effect of an applied treatment and how big it is, regardless whether it is diet correction or physical activity treatment (Rocha et al., 2018). This is even more pronounced with the advent of new technologies for the measurement of body components, based on the principle of bioimpedance, and especially new technology of multichannel multisegment bioimpedance as being very medically precise and easily available measurement technology for all body composition characteristics (Ling et al., 2011; Saraykin et al.).

From the perspective of anatomy, physiology and biology the female organism is very specific. Cyclical secretion of sex hormones during the reproductive period, pregnancy, childbirth, maternity, menopause, professional obligations and daily activities all have a great effect on body status (Thompson et al., 2004; Kukic et al., 2019).

On the other hand, along with a considerable number of published researches that tested body composition of women of various ages by applying the method of segmental multichannel bioimpedance (Gába \& Pridalová; Ihász et al.; Kukic et al., 2019) there are still no researches that define the standards and normatives for evaluating the status of two very important, if not the most important, body status characteristics, and those are: percentage of body fat (PBF) and percentage of skeletal muscles in the body (PSMM).

The goal of this paper is to define standards and normatives for evaluation of body status among women of various ages according to two variables: percentage of body fat $(\mathrm{PBF})$ and percentage of skeletal muscles in the body (PSMM), measured by the method of segmental multichannel bioimpedance. Acquired results will serve as a qualitative and quantitative criterion for evaluation of given variables among general population of healthy women of various ages, with regards to the medical, health and scientific aspect.

\section{MATERIAL AND METHOD}

This research belongs to the Transversal Survey Study, whereas regarding meauserement it belongs to the method of laboratory research with direct measurement. The sample of respondents was gathered via a randomized method with a combined approach to selecting the respondents (measurement announcements were given through the media, personal acquaintances and systematic testing of different companies).

Subjects Sample. The research was conducted on a sample of 1924 women $($ Ages $=35.5 \pm 10.8 \mathrm{yr}, \mathrm{BH}=168.3 \pm 7.2 \mathrm{~cm}$, $\mathrm{BM}=68.1 \pm 14.5 \mathrm{~kg}, \mathrm{BMI}=24.08 \pm 5.2 \mathrm{~km} \bullet \mathrm{m}-2 ; 47.6 \%$ of respondents were from the urban, $34.8 \%$ from suburban and $17.6 \%$ from rural areas; also, $46.3 \%$ were from the central, $33.9 \%$ from the southern, and $19.8 \%$ from the northern part of Republic of Serbia). At the time of the measurement all respondents were without acute clinical health problems. Measurements for the purpose of this study were conducted in the period between 2015 and 2018 using the same apparatus (InBody720) and applying the same measurement technology in two institutions: University of Belgrade's Faculty of Sport and Physical Education's and Faculty of Medicine's Institute for Hygiene and Medical Ecology in Belgrade. During the research period both measurement instruments were regularly maintenanced and calibrated according to the manufacturer's instructions.

All respondents have been informed as to the purpose of the research and have willingly consented to it. The research was realized in accordance with the roles of Declaration of Helsinki: Recommendations Guiding Physicians in Biomedical Research Involving Human Subjects (Christie, 2000).

Testing. Body composition was measured using the standardized method of multichannel bioelectrical impedance analysis (BIA). BIA machine InBody 720 (Biospace, Co., Ltd), with tetra-polar 8-point tactile electrode system sends bioelectrical currents of different frequencies, each of which estimates the amount of the corresponding 
tissue by the electrical resistance that certain tissue provides. InBody 720 was shown measurement reliability with $\mathrm{ICC}=$ 0.97, and comparing to DXA method correlate with $\mathrm{r}=0.93$ overall and segmental body composition in female (Ling et al.; Esco et al., 2015).

Variables. Only two variables were chosen for the purpose of this research, these being standardly used in defining the body status, and they represent relative values of the total mass of fat tissue and total mass of skeletal muscle tissue in relation to voluminosity dependence. All variables were analyzed with regards to the following six age groups: 18.0$19.9 \mathrm{yr}, 20.0-29.9 \mathrm{yr}, 30.0-39.9 \mathrm{yr}, 40.0-49.9 \mathrm{yr}, 50.0-59.9$ $\mathrm{yr}$, and 60.-69.9 yr, and the given variables were:

1. $\mathrm{PBF}$ - percentage of body fat mass, calculated as: relation between body fat (BF) and body mass (BM) in $\mathrm{kg}$, expressed in \%;

2. PSMM - percentage of skeletal muscle mass, calculated as: relation between skeletal muscle mass (SMM) and body mass $(\mathrm{BM})$ in $\mathrm{kg}$, expressed in $\%$.

Statistics. After the measurement all the results were transferred to Microsoft Excel database, where logical data verification was performed. After that they were subjected to basic descriptive analysis to calculate mean value (MEAN), standard deviation (SD), variation coefficient (cV $\%$ ), minimum and maximum values (Min and Max), as well as $95 \%$ confidence intervals of variables. For the purpose of defining measurement precision, as result validation of this multicentric study, standard measurement error (SEM) was calculated in relative values (in \%). Criteria values of distribution classes were defined at the level of 2.5, 5.0, 10.0, 25.0, 50.0, 75.0, 90.0, 95.0 and 97.5 percentiles, while procedure according to Zactsiorsky (Zatsiorsky, 1982) was used in relation to the athletic metrological criterion of qualitative definition of seven part normative (Zatsiorsky). Differences between analyzed age groups were established by applying a single variant variance analysis ANOVA, whereas Bonferoni post-hoc criterion was used for establishing the differences between individual pair groups. Trend analysis of observed phenomena in the function of age groups was defined with the help of linear regression analysis. The Statistical Package for Social Sciences (IBM, SPSS Statistics 20) was used for all statistical analyses, while the significance level was set at $95 \%$ level of confidence at $\mathrm{p}<0.05$ (Hair et al., 1998).

\section{RESULTS}

Basic descriptive results are shown in Table I.

Results showed that PBF among respondents is in the range of 23.81 to $39.94 \%$ for age groups 18.0-19.9 $\mathrm{yr}$ and 60.0-69.9 yr, respectively, with result variation at the level of $32.48 \%$, and standard measurement error of 1.71 $\%$. For the variable PSMM it was established that values are in the range of 42.25 to $32.58 \%$ for age groups $18.0-19.9 \mathrm{yr}$ and 60.0-69.9\%, respectively, with result variation at the level of $13.36 \%$, and standard measurement error of only $0.82 \%$.

Table I. Basic descriptive results of examined variables for the function of age groups

\begin{tabular}{|c|c|c|c|c|c|c|c|c|}
\hline & \multicolumn{8}{|c|}{$\operatorname{PBF}(\%)$} \\
\hline & \multirow{2}{*}{ Mean ( \%) } & \multirow{2}{*}{$\mathrm{SD}(\%)$} & \multirow{2}{*}{$\mathrm{cV}(\%)$} & \multirow{2}{*}{ SEM (\%) } & \multirow{2}{*}{$\operatorname{Min}(\%)$} & \multirow{2}{*}{$\operatorname{Max}(\%)$} & \multicolumn{2}{|c|}{$95 \%$ Conf. Int. } \\
\hline & & & & & & & Low. & Upper. \\
\hline All & 28.51 & 9.26 & 32.48 & 1.71 & 5.82 & 55.75 & 27.54 & 29.48 \\
\hline $18.0-19.9 \mathrm{yr}$ & 23.81 & 6.77 & 28.43 & 2.42 & 9.98 & 52.47 & 22.68 & 24.94 \\
\hline $20.0-29.9 \mathrm{yr}$ & 24.77 & 7.40 & 29.87 & 1.26 & 5.82 & 55.28 & 24.16 & 25.38 \\
\hline $30.0-39.9 \mathrm{yr}$ & $28.14^{*, \pm}$ & 9.25 & 32.87 & 1.31 & 7.04 & 55.75 & 27.42 & 28.87 \\
\hline $40.0-49.9 \mathrm{yr}$ & $32.42^{*, \mathfrak{x}}$ & 8.27 & 25.51 & 1.41 & 11.92 & 55.18 & 31.53 & 33.32 \\
\hline $50.0-59.9 \mathrm{yr}$ & 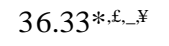 & 7.90 & 21.75 & 1.64 & 13.58 & 51.82 & 35.16 & 37.49 \\
\hline \multirow[t]{2}{*}{$60.0-69.9 \mathrm{yr}$} & $39.94 *, \mathrm{*}, \ldots, ¥, \#$ & 7.91 & 19.80 & 2.23 & 19.94 & 55.15 & 38.20 & 41.69 \\
\hline & \multicolumn{8}{|c|}{$\operatorname{PSMM}(\%)$} \\
\hline All & 39.30 & 5.25 & 13.36 & 0.82 & 19.35 & 55.10 & 38.67 & 39.93 \\
\hline $18.0-19.9 \mathrm{yr}$ & 42.25 & 3.83 & 9.07 & 0.77 & 27.11 & 50.74 & 41.62 & 42.89 \\
\hline $20.0-29.9 \mathrm{yr}$ & 41.37 & 4.30 & 10.39 & 0.42 & 24.80 & 55.10 & 41.03 & 41.72 \\
\hline $30.0-39.9 \mathrm{yr}$ & $39.47^{*, \mathrm{x}}$ & 5.18 & 13.12 & 0.53 & 19.35 & 51.51 & 39.07 & 39.88 \\
\hline $40.0-49.9 \mathrm{yr}$ & $37.17^{*, \mathfrak{x},-}$ & 4.58 & 12.32 & 0.69 & 25.18 & 51.84 & 36.66 & 37.67 \\
\hline $50.0-59.9 \mathrm{yr}$ & $34.73^{*, \mathrm{t}, \_\neq}$ & 4.35 & 12.53 & 0.96 & 23.94 & 47.17 & 34.08 & 35.39 \\
\hline $60.0-69.9 \mathrm{yr}$ & $32.58^{*, f, \ldots, \neq \#}$ & 4.19 & 12.86 & 1.54 & 24.94 & 49.84 & 31.60 & 33.56 \\
\hline
\end{tabular}

* 18-19.9 vs 20-29.9, 30-39.9, 40-49.9, 50-59.9, 60-69.9, p $\leq 0.05$; £ 20-29.9 vs 30-39.9, 40-49.9, 50-59.9, 60-69.9, p $\leq 0.05 ; \propto$ a 30-39.9 vs 40-49.9, $50-59.9,60-69.9, \mathrm{p} \leq 0.05 ; ¥ 40-49.9$ vs 50-59.9, 60-69.9, $\mathrm{p} \leq 0.05 ; \# 50-59.9$ vs $60-69.9, \mathrm{p} \leq 0.05$. 
ANOVA results with differences between the examined age groups for the function of individual variables are shown in Table II.

It was established that there are statistically significant differences between groups in relation to both examined variables at the level of $\mathrm{p}=0.000$, where the variable PBF carries $24.6 \%$, and variable PSMM carries $25.6 \%$ of established differences between age groups, with the power analysis at the level of $100 \%$, respectively (Table II).
Results of percentile distribution of all variables for the function of examined age groups as well as qualitativenormative values of examined variables were presented within Tables III and IV.

Trends of change of analysed variables for the function of age groups are shown in Figures 1 and 2, with defined prediction models.

Table II. ANOVA results - differences between groups with regards to examined variables (PBF and PSMM).

\begin{tabular}{lccccccc}
\hline & \multicolumn{7}{c}{ Tests of Between-Subjects Effects } \\
Source & Type III Sum of Squares & df & Mean Square & F & Sig. & Partial Eta $^{2}$ & Observed Power $^{\mathrm{b}}$ \\
\hline PBF & 40398.958 & 5 & 8079.79 & 124.78 & 0.000 & 0.246 & 1.000 \\
PSMM & 13520.827 & 5 & 2704.17 & 131.51 & 0.000 & 0.256 & 1.000 \\
\hline
\end{tabular}

Table III. Results of percentile distribution of all variables for the function of examined age groups.

\begin{tabular}{cccccccccc}
\hline Variables & \multicolumn{7}{c}{ Percentile } \\
\hline PBF ( \%) & $\mathbf{2 . 5}$ & $\mathbf{5 . 0}$ & $\mathbf{1 0 . 0}$ & $\mathbf{2 5 . 0}$ & $\mathbf{5 0 . 0}$ & $\mathbf{7 5 . 0}$ & $\mathbf{9 0 . 0}$ & $\mathbf{9 5 . 0}$ & $\mathbf{9 7 . 5}$ \\
\hline All Sample & 13.96 & 15.77 & 17.84 & 21.57 & 27.04 & 34.50 & 42.27 & 46.10 & 49.03 \\
$18.0-19.9 \mathrm{yr}$ & 13.62 & 14.96 & 16.58 & 19.58 & 23.08 & 26.72 & 31.07 & 35.82 & 45.89 \\
$20.0-29.9 \mathrm{yr}$ & 12.95 & 14.57 & 16.49 & 20.12 & 23.51 & 28.88 & 34.38 & 38.15 & 42.63 \\
$30.0-39.9 \mathrm{yr}$ & 13.74 & 15.06 & 17.81 & 21.34 & 26.56 & 33.89 & 41.46 & 46.15 & 50.34 \\
$40.0-49.9 \mathrm{yr}$ & 17.68 & 19.20 & 22.14 & 26.51 & 32.07 & 38.18 & 43.71 & 46.29 & 48.29 \\
$50.0-59.9 \mathrm{yr}$ & 22.22 & 23.32 & 26.34 & 30.60 & 36.13 & 42.34 & 47.17 & 49.97 & 50.81 \\
$60.0-69.9 \mathrm{yr}$ & 17.45 & 24.80 & 29.67 & 35.21 & 40.51 & 45.41 & 48.99 & 50.93 & 54.87 \\
PSMM ( \%) & $\mathbf{2 . 5}$ & $\mathbf{5 . 0}$ & $\mathbf{1 0 . 0}$ & $\mathbf{2 5 . 0}$ & $\mathbf{5 0 . 0}$ & $\mathbf{7 5 . 0}$ & $\mathbf{9 0 . 0}$ & $\mathbf{9 5 . 0}$ & $\mathbf{9 7 . 5}$ \\
All Sample & 27.77 & 29.57 & 31.69 & 35.95 & 40.00 & 43.11 & 45.44 & 47.08 & 48.07 \\
$18.0-19.9 \mathrm{yr}$ & 30.43 & 35.36 & 37.67 & 40.38 & 42.48 & 44.81 & 46.50 & 47.66 & 48.58 \\
$20.0-29.9 \mathrm{yr}$ & 31.80 & 33.91 & 35.86 & 38.79 & 41.86 & 44.14 & 46.23 & 47.78 & 48.55 \\
$30.0-39.9 \mathrm{yr}$ & 27.39 & 29.83 & 32.24 & 36.08 & 40.27 & 43.27 & 45.17 & 47.30 & 47.96 \\
$40.0-49.9 \mathrm{yr}$ & 28.32 & 29.72 & 30.91 & 34.21 & 37.29 & 40.33 & 43.09 & 44.52 & 45.95 \\
$50.0-59.9 \mathrm{yr}$ & 26.84 & 27.54 & 28.90 & 31.39 & 34.82 & 37.83 & 39.80 & 41.70 & 43.06 \\
$60.0-69.9 \mathrm{yr}$ & 25.07 & 26.99 & 27.36 & 29.64 & 32.43 & 34.79 & 38.07 & 39.59 & 42.71 \\
\hline
\end{tabular}

Table IV. Qualitative-normative values of examined variables.

\begin{tabular}{|c|c|c|c|c|c|c|}
\hline & $18.0-19.9 \mathrm{yr}$ & $20.0-29.9 \mathrm{yr}$ & $30.0-39.9 \mathrm{yr}$ & $40.0-49.9 \mathrm{yr}$ & $50.0-59.9 \mathrm{yr}$ & $60.0-69.9 \mathrm{yr}$ \\
\hline & \multicolumn{6}{|c|}{$\operatorname{PBF}(\%)$} \\
\hline Superior & $\leq 10.2$ & $\leq 10.0$ & $9.6 \leq$ & $15.8 \leq$ & $20.4 \leq$ & $24.1 \leq$ \\
\hline Excellent & $10.3-17.0$ & $10.1-17.4$ & $9.7-18.8$ & $15.9-24.1$ & $20.5-28.4$ & $24.2-32.0$ \\
\hline Above Avg. & $17.1-20.4$ & $17.5-21.1$ & $18.9-23.5$ & $24.2-28.2$ & $28.5-32.3$ & $32.1-35.9$ \\
\hline Average & $20.5-27.2$ & $21.2-28.5$ & $23.6-32.7$ & $28.3-36.6$ & $32.4-40.2$ & $36.0-43.8$ \\
\hline Under Avg. & $27.3-30.5$ & 28.6-32.2 & $32.8-37.3$ & $36.7-40.6$ & $40.3-44.2$ & $43.9-47.8$ \\
\hline Bad & $30.6-37.3$ & $32.3-39.6$ & $37.4-46.6$ & $40.70-48.9$ & $44.3-52.1$ & $47.9-55.6$ \\
\hline \multirow[t]{2}{*}{ Very Bad } & $37.4 \geq$ & $39.7 \geq$ & $46.7 \geq$ & $49.0 \geq$ & $52.2 \geq$ & $55.9 \geq$ \\
\hline & \multicolumn{6}{|c|}{ PSMM $(\%)$} \\
\hline Superior & $\geq 49.9$ & $\geq 49.9$ & $49.8 \geq$ & $46.3 \geq$ & $43.4 \geq$ & $41.0 \geq$ \\
\hline Excellent & $49.8-46.1$ & $49.8-45.7$ & $49.7-44.6$ & $46.2-41.8$ & $43.3-39.1$ & $40.9-36.8$ \\
\hline Above Avg. & $46.0-44.2$ & $45.6-43.5$ & $44.5-42.1$ & 41.7-39.5 & $39.0-36.9$ & $36.7-34.8$ \\
\hline Average & $44.1-40.4$ & $43.4-39.2$ & $42.0-36.9$ & $39.4-34.9$ & $36.8-32.6$ & $34.7-30.5$ \\
\hline Under Avg. & $40.3-38.4$ & $39.1-37.1$ & $36.8-34.3$ & $34.8-32.6$ & $32.5-30.4$ & $30.4-28.4$ \\
\hline Bad & $38.3-34.6$ & $37.0-32.7$ & $34.2-29.1$ & $32.5-28.1$ & $30.3-26.1$ & $28.3-24.2$ \\
\hline Very Bad & $\leq 34.5$ & $\leq 32.6$ & $29.0 \leq$ & $28.0 \leq$ & $26.0 \leq$ & $24.1 \leq$ \\
\hline
\end{tabular}




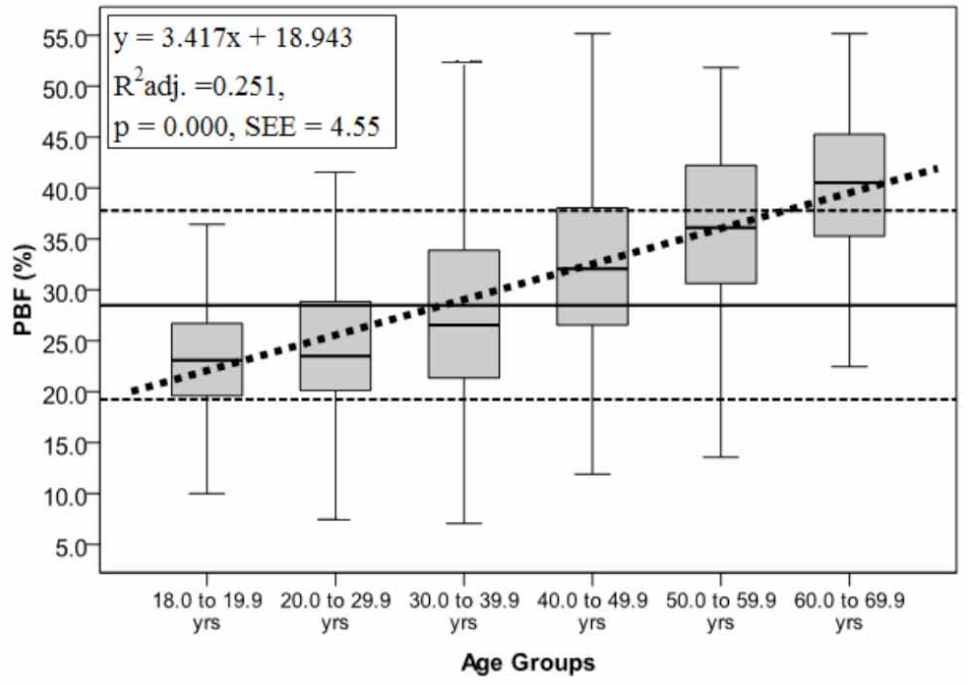

Fig. 1. PBF change trend in relation to examined age groups.

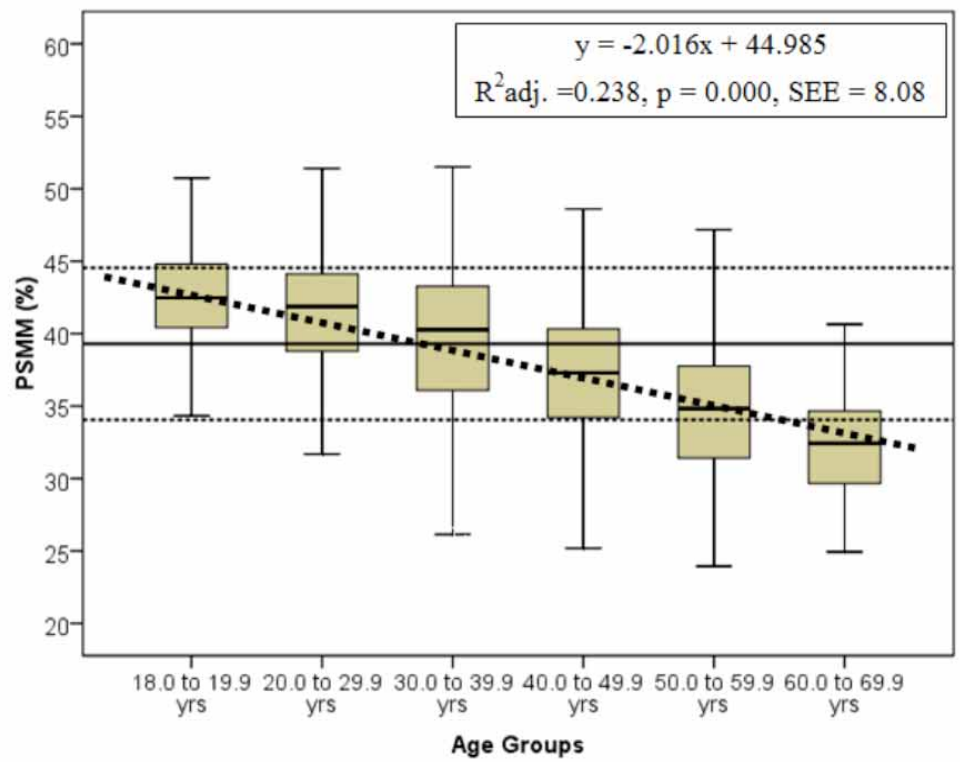

Fig. 2. PSMM change trend in relation to examined age groups

\section{DISCUSSION}

Besides basic morphologic variables, that is, variables providing information about absolute measurements of body composition, index (derived) variables that give data on the relative presence of a certain element in the body have a great practical and medically diagnostic value (De Rosa et al., 2015; Maksimovic et al., 2016). One of the most valid index variables are partialized in relation to the extent of body voluminosity by which body status is evaluated, along with variables by which fat percentage and skeletal muscle percentage are defined (PBF and PSMM, respectively) (Ling et al.; Gába \& Pridalová; Bankovic et al.).
According to data published in the most recent researches it has been shown that, year after year, the level of PBF value is on the rise among all the age categories of the population in the area of Serbia (Boricic et al., 2014). In the period between two researches, from 2006 and 2013, a significant degree of increase of obese population was established (from $17.3 \%$ to 21.2 $\%$ ), especially in the age category of 45-84 (Boricic et al.). According to the results of this research it was established (Table I) that the average $\mathrm{PBF}$ value is at the level of $28.51 \pm 9.26 \%$ of body fat, from $23.81 \%$ for the youngest (18.0$19.9 \mathrm{yr}$ of age) to $39.94 \%$ for the oldest sample (60.0-69.9 yr).

With regards to age groups, a high statistically significant difference was found between almost everyone (Table II, ANOVA F = $124.775, \mathrm{p}=0.000)$, in a way that apart from the two youngest ones differing from each other (18.0-19.9 yr and 20.0-29.9 yr) all the other groups differ among themselves crosswise (Table I). In other words, the percentage of body fat among respondents was not different from 18.0 all until the age of 29.9, whereas after that age, i.e. from $30.0 \mathrm{yr}$ of age onwards, it increased in a statistically significant way, decade after decade all up to $69.9 \mathrm{yr}$ of age. Regression analysis results have shown that the constant of body fat percentage increase amounted to $3.417 \%$ per life decade, and that the defined regression model explains $25.1 \%$ of mutual trend variance (Fig. 1). However, only a $1 / 4$ of the examined phenomenon was explained by the defined equation model (PBF $=3.417 \cdot$ age group +18.943 ). With the remaining $3 / 4$ of the sample the PBF value change occurs differently from the defined trend of $4.55 \%$, i.e. either at a higher or a lower level. This only points to the complexity of the examined phenomenon, as well as to multidimensionality of factors that influence body status in the sense of change in the body fat in females during their life, and especially after $30.0 \mathrm{yr}$ of life. It was previously found that different social, life and health factors, such as raising a family, maternity status, hormone status, professional-work environment and obligations, level of physical activity, diet habits etc. significantly influence variability factor of body composition changes among women (Thompson et al.; Menotti et al.; Gába \& Pridalová; Sarayakin et al., 2018; Kukic et al., 2019). 
RAKIC, S.; DOPSAJ, M.; DJORDJEVIC-NIKIC, M.; VASILJEVIC, N.; DOPSAJ, V.; MAKSIMOVIC, M.; TOMANIC, S. M. \& MILJUS, D. Profile and reference values for body fat and skeletal muscle mass percent at females, aged from 18.0 to 69.9, measured by multichannel segmental bioimpedance method: Serbian population study. Int. J. Morphol., 37(4):1286-1293, 2019.

In a research conducted using the same measurement method and the same instrument, on a sample of women from Czech Republic, an average PBF value at the level of $29.1 \pm 8.9 \%$ was measured. Range of results in relation to age groups was from $23.5 \pm 5.9 \%$ for the group aged 18-29 $\mathrm{yr}, 26.3 \pm 7.2 \%$ for the group aged $30-39 \mathrm{yr}, 29.3 \pm 7.4 \%$ for the group aged $40-49 \mathrm{yr}, 34.7 \pm 7.7 \%$ for the group aged 50 $59 \mathrm{yr}$ and $36.0 \pm 6.5 \%$ for the group aged 60-69 yr (Gába \& Pridalová). Generally speaking, even though our results are greater on average than the Czech by about $3.0 \%$, it can be claimed that the results of both studies are still very similar when it comes to PBF values. This only serves as proof of the external scientific validity of our results in relation to women from the Eastern European region. The established difference in PBF of about $3.0 \%$ among Serbian women can most probably be ascribed to the fact that respondents in this study were women $3.6 \mathrm{~cm}$ taller $(168.3 \mathrm{vs} 164.7 \mathrm{~cm}$, difference of $2.14 \%$ ) and $2.6 \mathrm{~kg}$ heavier (68.1 vs $65.5 \mathrm{~kg}$, difference $3.82 \%$ ), i.e. they were $2.98 \%$ physically larger than the women from the Czech research.

The next two researches performed using the same measurement methodology and the application of the same instrument, where some respondents were from the same European region, i.e. Hungary (Ihász et al.), and the others from the region of Arabian Peninsula, i.e. from the UAE, Abu Dhabi to be precise (Kukic et al., 2019), showed that the average PBF value among Hungarian women was at the level of $34.32 \%$, and among those from UAE $40.09 \%$. When compared to Serbian women, respondents from Hungary had $16.9 \%$ more body fat on average, whereas the UAE respondents had $28.9 \%$ more, respectively.

These differences, i.e. the greater amount of body fat in the sample of women from Hungary, are a probably consequence of numerous factors, with different diet habits being one of the most probable. Namely, according to the data from a recently published epidemiological study (Grasgruber et al., 2016), it was found that differences in diet significantly influence prevalence, and also cause the rise in incidence of non-infectious diseases in the context of citizens from different European countries. It is stressed in the results that a more significant connection among women than among men was established with regards to total fat and animal protein intake and other indicators of fat and protein intake, where it was found that the level of total fat consumption among Hungarian women amounts to over $130 \mathrm{~g} / \mathrm{day}$, while it is at the level of 118 and $110 \mathrm{~g} /$ day among women from Czech Republic and Serbia, respectively (Grasgruber et al.). When it comes to the UAE women, aside from those already mentioned, differences can also be ascribed to ethnicity in the sense of social and cultural heritage, as well as to geographical and climate environment (Kukic et al.).
In relation to results of skeletal muscle percentage in the body (Table I, PSMM) it was established that the average value is at the level of $39.30 \pm 5.25 \%$, and that it is within range of $42.25 \%$ for the youngest sample (18.0-19.9 $\mathrm{yr}$ of age) to $32.58 \%$ for the oldest sample (60.0-69.9 yr). In the research conducted using the same measurement method and instrument, on the sample of Hungarian women (Ihász et al.) and UAE women (Kukic et al., 2019) an average PSMM value at the level of $35.79 \%$ was measured, i.e. $32.73 \%$, which is an $8.93 \%$, i.e. $20.06 \%$ smaller percentage of skeletal muscles in the body when compared to the results of this study, which proves the validity of the variable in relation to international researches of the skeletal muscle amount status among women of different nationality and race.

A high statistically significant difference was found between almost everyone (Table II, ANOVA F $=131.506, \mathrm{p}=$ $0.000)$, and apart from the two youngest groups differing from each other (18.0-19.9 and 20.0-29.9) all the other older age groups differ crosswise (Table I). As in the case of PBF, percentage of muscle presence in the body was similar with respondents who are 18.0 all up to 29.9 yr of age, whereas it decreased in a statistically significant way after that age, i.e. after $30.0 \mathrm{yr}$ of life, decade after decade, all until $69.9 \mathrm{yr}$ of life.

Regression analysis results showed that the constant of decrease in percentage of skeletal muscle in the body amounted to $-2.016 \%$ per life decade, and also that $23.8 \%$ of mutual variance trend was explained by the defined regression model (Fig. 2). As in the case of PBF, only about $1 / 4$ of the examined phenomenon was explained by the defined equation model $(\mathrm{PSMM}=-2.016 \cdot$ age group + $44.985)$, with evaluation error of $8.08 \%$, while with the remaining $3 / 4$ of the sample change in the value of PSMM occurs differently from the defined trend. As in the case of this variable, this only points to the complexity and multidimensionality of the examined phenomenon, in a way that a greater number of factors influence body status in the sense of change in the amount of skeletal muscle in the organism among women during their life, and especially after $30.0 \mathrm{yr}$ of life. Generally speaking, this variable is directly dependent on the total body mass and the amount of SMM (since it belongs to it) which was previously established as gradually declining, especially after the $30^{\text {th }}$ year. Previous results have shown that body mass declines at the rate of between $3 \%$ and $8 \%$ for each life decade after the year 30, while the degree of muscle mass loss is increased to 5 and up to $10 \%$ or about $0.4 \mathrm{~kg}$ a year per every life decade after the $50^{\text {th }}$ year (Janssen et al., 2000).

When the age effect on the variable PSMM is concerned, it was found that between the 18 and 40 year it is not connected to the absolute muscle mass in the body, 
because the increase of total body mass up to the 40th year of age occurs based on the mechanism of fat tissue increase, regardless of sex. Only after year 50 there occurs the beginning of absolute decrease of skeletal muscle mass, i.e. a real decline of PSMM, as such, where the decrease in SMM approximated 1.9 and $1.1 \mathrm{~kg} / \mathrm{dec}$ ade in the men and women, respectively (Janssen et al.).

Based on the results of this research it can be stated that the average value of body fat percentage among Serbian women is at the level of $28.51 \pm 9.26 \%$ and also that presence of fat tissue in the body in examined women is increased by a trend of $3.417 \%$ per decade. A statistically significant increase in the percentage of body fat starts after the year 30.0 , i.e. from the third decade of life. When it comes to presence of skeletal muscles in the body, it was found that the average value was $39.30 \pm 5.25 \%$, and that the presence of skeletal muscle tissue in the body of examined women is decreasing by a trend of $-2.016 \%$ per decade. A statistically significant decrease in the percentage of skeletal muscles in the body starts after the year 30.0, i.e. from the third decade of life on. Results of this study are in agreement with the findings of previous researches in relation to change of given variables depending on age, while the defined standards can for now be used from a practical aspect as well, on a national level, and also comparatively with regards to scientific needs of international researches.

\section{ACKNOWLEDGEMENTS}

The paper is a part of the national project III47015, funded by the Ministry of Education, Science and Technological Development of the Republic of Serbia Scientific Project 2011-2019.

RAKIC, S.; DOPSAJ, M.; DJORDJEVIC-NIKIC, M.; VASILJEVIC, N.; DOPSAJ, V.; MAKSIMOVIC, M.; TOMANIC, S. M. \& MILJUS, D. Perfil y valores de referencia del porcentaje de grasa corporal y masa muscular en mujeres, con edades comprendidas entre 18,0 y 69,9 años, medido por el método de bioimpedancia segmentaria multicanal: Estudio en población Serbia. Int. J. Morphol., 37(4):1286-1293, 2019.

RESUMEN: El perfil y estándares para el diagnóstico del porcentaje de grasa corporal y masa muscular fueron definidos en una muestra de 1924 mujeres de la República de Serbia, con edades comprendidas entre 18,0 y 69,9 años, donde la composición corporal de los sujetos fue medida por bioimpedancia segmentaria multicanal. La muestra fue dividida en seis grupos, con el propósito de definir los estándares respecto a la edad. Respecto al porcentaje de grasa corporal los resultados han mostrado que el valor promedio de la muestra fue de $28,51 \pm 9,26 \%$, y entre los rangos de 23,81 y 39,94 para los grupos de edad de $18,0-19,9$ años y 60,0 69,9 años, respectivamente. Los resultados del análisis de regresión mostraron que la constante del porcentaje de grasa corporal aumentó $3,417 \%$ por década, y que un $25,1 \%$ de la varianza fue explicada por el modelo, con un error de predicción de 4,55 \%. Con respecto al porcentaje de masa muscular, los resultados han mostrado que el valor promedio de la muestra fue de 39,30 $\pm 5,25$ $\%$, y entre los rangos de 42,24 y 32,58 para los grupos de edad de 18,0-19,9 años y 60,0-69,9 años, respectivamente. Los resultados del análisis de regresión han mostrado que la constante de masa muscular decreció $-2,016 \%$ por década y que el modelo explicó $23,8 \%$ de la varianza con un error de predicción de 8,08\%.

PALABRAS CLAVE: Mujeres; Perfil de composición corporal; Bioimpedancia; Grasa corporal; Masa muscular esquelética.

\section{REFERENCES}

Bankovic, V.; Dopsaj, M.; Terzic, Z. \& Nesic, G. Descriptive body composition profile in female olympic volleyball medalists defined using multichannel bioimpedance measurement: Rio 2016 team case study. Int. J. Morphol., 36(2):699-708, 2018.

Boricic, K.; Vasic, M.; Grozdanov, J.; Rakic, J.G.; Sulovic-Zivkovic, M.; Knezevic-Jacovic, N.; Jovanovic, V.; Kilibarda, B.; Knezevic, T.; Krstic, M.; et al., Rezultati istrazivanja zdravlja stanovnistva Srbije: 2013. godina. Beograd, Sluzbeni glasnik, 2014.

Christie, B. Doctors revise Declaration of Helsinki. B. M. J., 321(7266):913, 2000

De Rosa, E.; Santarpia, L.; Marra, M.; Sammarco, R.; Amato, V.; Onufrio, M.; De Simone, G.; Contaldo, F. \& Pasanisi, F. Preliminary evaluation of the prevalence of sarcopenia in obese patients from Southern Italy. Nutrition, 31(1):79-83, 2015.

Dopsaj, M.; Markovic, M.; Kasum, G.; Jovanovic, S.; Koropanovski, N.; Vukovic, M. \& Mudric, M. Discrimination of different body structure indexes of elite athletes in combat sports measured by multi frequency bioimpedance method. Int. J. Morphol., 35(1):199-207, 2017.

Esco, M. R.; Snarr, R. L.; Leatherwood, M. D.; Chamberlain, N. A.; Redding, M. L.; Flatt, A. A.; Moon, J. R. \& Williford, H. N. Comparison of total and segmental body composition using DXA and multifrequency bioimpedance in collegiate female athletes. J. Strength Cond. Res., 29(4):918-25, 2015

Gába, A. \& Pridalová, M. Age-related changes in body composition in a sample of Czech women aged 18-89 yr: a cross-sectional study. Eur. J. Nutr., 53(1):167-76, 2014.

Grasgruber, P.; Sebera, M.; Hrazdira, E.; Hrebickova, S. \& Cacek, J. Food consumption and the actual statistics of cardiovascular diseases: an epidemiological comparison of 42 European countries. Food Nutr. Res., 60:31694, 2016

Hair, J.; Anderson, R.; Tatham, R. \& Black, W. Multivariate Data Analysis. $5^{\text {th }}$ ed. New Jersey, Prentice-Hall Inc., 1998.

Hallal, P. C.; Andersen, L. B.; Bull, F. C.; Guthold, R.; Haskell, W.; Ekelund, U. \& Lancet Physical Activity Series Working Group. Global physical activity levels: surveillance progress, pitfalls, and prospects. Lancet, 380(9838):247-57, 2012.

Haskell, W. L.; Lee, I. M.; Pate, R. R.; Powell, K. E.; Blair, S. N.; Franklin, B. A.; Macera, C. A.; Heath, G. W.; Thompson, P. D. \& Bauman, A. Physical activity and public health: updated recommendation for adults from the American College of Sports Medicine and the American Heart Association. Med. Sci. Sports Exerc., 39(8):1423-34, 2007. 
Ihász, F.; Finn, K. J.; Lepes, J.; Halasi, S. \& Szabó, P. Body composition comparisons by age groups in Hungarian adults. Int. J. Morphol., 33(3):850-4, 2015.

Janssen, I.; Heymsfield, S. B.; Wang, Z. M. \& Ross, R. Skeletal muscle mass and distribution in 468 men and women aged 18-88 yr. J. Appl. Physiol. (1985), 89(1):81-8, 2000.

Kukic, F.; Scekic, A.; Koropanovski, N.; Cvorovic, A.; Dawes, J. J. \& Dopsaj, M. Age-related body composition differences in female police officers. Int. J. Morphol., 37(1):302-7, 2019.

Ling, C. H.; de Craen, A. J.; Slagboom, P. E.; Gunn, D. A.; Stokkel, M. P.; Westendorp, R. G. \& Maier, A. B. Accuracy of direct segmental multifrequency bioimpedance analysis in the assessment of total body and segmental body composition in middle-aged adult population. Clin. Nutr., 30(5):610-5, 2011.

Maksimovic, M. Z.; Gudelj Rakic, J. M.; Vlajinac, H. D.; Vasiljevic, N. D. \& Marinkovic, J. M. Relationship between health behaviour and body mass index in the Serbian adult population: data from National Health Survey 2013. Int. J. Public Health, 61(1):57-68, 2016.

Menotti, A.; Puddu, P. E.; Lanti, M.; Maiani, G.; Catasta, G. \& Fidanza, A. A. Lifestyle habits and mortality from all and specific causes of death: 40-year follow-up in the Italian Rural Areas of the Seven Countries Study. J. Nutr. Health Aging, 18(3):314-21, 2014.

Owen, N.; Sparling, P. B.; Healy, G. N.; Dunstan, D. W. \& Matthews, C. E. Sedentary behavior: emerging evidence for a new health risk. Mayo Clin. Proc., 85(12):1138-41, 2010.

Rocha, C. A. Q. C.; Guimarães, A. C.; Maia, B. D. C.; Santos, C. A.; Moreira, M. H. R.; Dantas, E. H. M.; Ochoa-Martínez, P. Y.; Hall-López, J. A. \& Alarcón-Meza, E. I. Effects of a 20-week concurrent training program on bone metabolism in elderly women. Int. J. Morphol., 36(2):655-60, 2018.

Sallis, R.; Franklin, B.; Joy, L.; Ross, R.; Sabgir, D. \& Stone, J. Strategies for promoting physical activity in clinical practice. Prog. Cardiovasc. Dis., 57(4):375-86, 2015.

Saraykin D.; Khusnutdinova A.; Pavlova V.; Kamskova Y. \& Yushkov B. Adaptation of professional athletes to various physical loads by means of body composition changes. Hum. Sport Med., 18(3):47-59, 2018.

Thompson, D. L.; Rakow, J. \& Perdue, S. M. Relationship between accumulated walking and body composition in middle-aged women. Med. Sci. Sports Exerc., 36(5):911-4, 2004.

Zatsiorsky, V. Sports Metrology. Moscow, Physical Education and Sports, 1982.

\author{
Corresponding author: \\ Sladjana Rakic \\ Faculty of Sport and Physical Education \\ University of Belgrade \\ Blagoja Parovica 156 \\ Belgrade \\ SERBIA
}

Email: sladjana_rakic@yahoo.com

Received: 09-02-2019

Accepted: 23-05-2019 